TREE RINGS AS INDICATORS

OF HYDROLOGIC CHANGE IN THE GREAT DISMAL SWAMP, VIRGINIA AND NORTH CAROLINA

PHIPPS, R.L., D.L. Ireley, \$ C.P. Baker 1978 


\begin{tabular}{|l|l|l|}
\hline REPORT DOCUMENTATION & 1. REPORT NO. & 2. \\
PAGE
\end{tabular}

4. Title and Subtitle

TREE RINGS AS INDICATORS OF HYDROLOGIC CHANGE IN THE GREAT DISMAL SWAMP, VIRGINIA AND NORTH CAROLINA

7. Author(s)

R.L.Phipps, D.L. Ierley and C.P. Baker

9. Performing Organization Name and Address

U.S. Geological Survey, Water Resources Division

National Center, Mail Stop \#461

12201 Sunrise Valley Drive

Reston, Virginia 22092

12. Sponsoring Organization Name and Address

U.S. Geological Survey, Water Resources Division

National Center, Mail Stop \#461

12201 Sunrise Valley Drive

Reston, Virginia 22092

15. Supplementary Notes
3. Recipient's Accession No

5. Report Date

November 1978

6.

8. Performing Organization Rept. No.

USGS/WRI - 78-136

10. Project/Task/Work Unit No.

11. Contract(C) or Grant(G) No.

(C)

(G)

13. Type of Report \& Period Covered

Interim

14.

16. Abstract (Limit: 200 words) Analys is of tree rings of large, canopy 1oblolly pines (Pinus taeda L. growing near a drainage ditch in the Great Dismal Swamp have indicated that the tree ring are datable and hydrologically (climatically) sensitive. Climatic and prior growth factors in regression explained 87 and 71 percent of the variance of the preditching and postditching earlywood widths, respectively, and 82 and 70 percent of the latewood widths for the same time periods. Early summer precipitation was significantly, and positively correlated with preditching latewood growth. When pre- and post-ditching records were merged into a single record, regression analysis explained less growth variation than whe the two time periods were considered individually, implying a change in growth response following ditching. Prior to ditching, growth was most limited by dry summers which followed dry summers. After ditching, growth was less strongly linked with precipitation and more strongly linked with temperature. Regression results are compatible with the contention that growing season water levels in the proximity of the collection site have been lower since ditching.

17. Document Analysis a. Descriptors

Dendrochronolgy, swamps, loblolly pine trees, ditches, alteration of flow

b. Identifiers/Open-Ended Terms

Dendroclimatologic calibration

c. COSATI Field/Group

18. Availability Statement

Release unlimited

19. Security Class (This Report) Unclassified

20. Security Class (This Page)

Unclassified
21. No. of Pages ?n 22. Price 


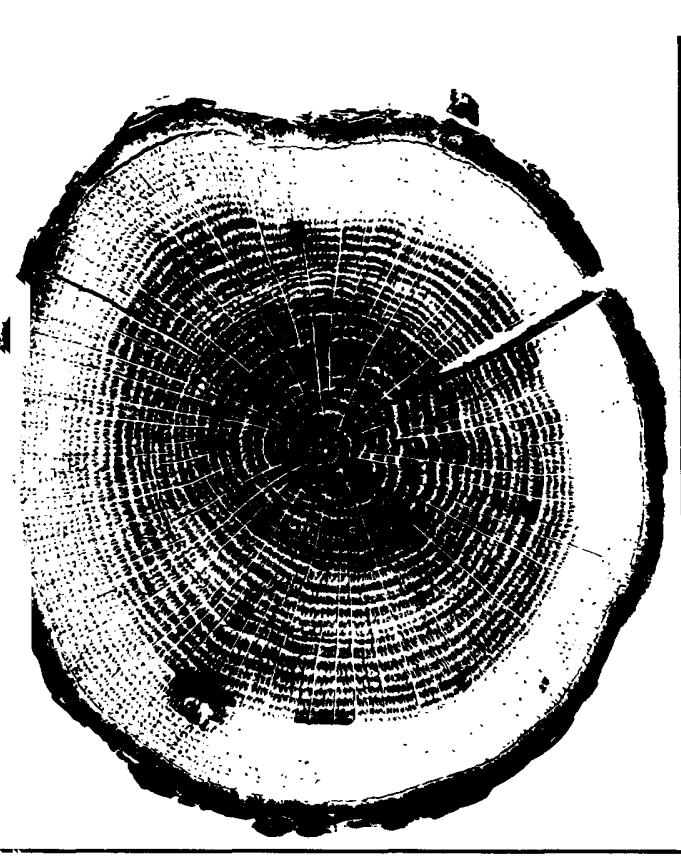

TREE RINGS AS INDICATORS OF HYDROLOGIC CHANGE IN THE GREAT DISMAL SWAMP, VIRGINIA AND NORTH CAROLINA by R.L. PHIPPS, D.L. IRELEY and C.P. BAKER 
UNITED STATES DEPARTMENT OF THE INTERIOR CECIL D. ANDRUS, Secretary

GEOLOGICAL SURVEY

H. William Menard, Director

For additional information write to:

Chief Hydrologist

U.S. Geological Survey, WRD

461 National Center

Reston, Virginia 22092 
Abstract $\ldots \ldots \ldots \ldots \ldots \ldots \ldots \ldots \ldots \ldots \ldots \ldots \ldots \ldots \ldots \ldots \ldots \ldots \ldots \ldots \ldots$

Introduction $\ldots \ldots \ldots \ldots \ldots \ldots \ldots \ldots \ldots \ldots \ldots \ldots \ldots \ldots \ldots \ldots \ldots$

The Study Area $\ldots \ldots \ldots \ldots \ldots \ldots \ldots \ldots \ldots \ldots \ldots \ldots \ldots \ldots \ldots \ldots \ldots$

Tree-Ring Data ............................... 7

Climatic Data $\ldots \ldots \ldots \ldots \ldots \ldots \ldots \ldots \ldots \ldots \ldots \ldots \ldots \ldots \ldots \ldots \ldots$

General Observations .......................... 8

Regression Analysis ............................ 11

Summary and Conclusions $\ldots \ldots \ldots \ldots \ldots \ldots \ldots \ldots \ldots \ldots \ldots \ldots \ldots$

References $\ldots \ldots \ldots \ldots \ldots \ldots \ldots \ldots \ldots \ldots \ldots \ldots \ldots \ldots \ldots \ldots \ldots \ldots \ldots \ldots$ 


\section{ILLUSTRATIONS}

Page

Figure 1. Sketch map showing location of study area in

Great Dismal Swamp....................... 3

2. Graph of filtered ring width data............ 12

3. Graph of filtered temperature and precipitation data for Elizabeth City, North Carolina.......... 13

4. Graph of stepwise multiple regression results between tree rings and climate................

5. Diagram showing changes in growth response to rainfall after ditching................... 


\section{TABLES}

Page

Table 1. Statistical characteristics of ring width, earlywood and latewood chronologies............

2. Basal area growth of 11 loblolly pines for 20-year increments before and after ditching......

3. Percent variance accounted for by regression between tree rings and climate................

4. Conditions resulting in narrow rings in

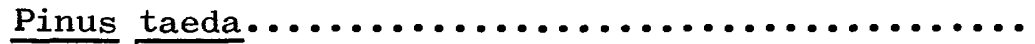

5. Years of small tree rings between 1830-1950...... 


$$
\text { • }
$$




\title{
TREE RINGS AS INDICATORS OF HYDROLOGIC CHANGE IN THE GREAT DISMAL SWAMP, VIRGINIA AND NORTH CAROLINA
}

\author{
By R. L. Phipps, D. L. Ierley, and C. P. Baker
}

\section{ABSTRACT}

\begin{abstract}
Analyses of tree rings of large, canopy loblolly pines (Pinus taeda $L_{.}$) growing near a drainage ditch in the Great Dismal Swamp have indicated that the tree rings are datable and hydrologically (climatically) sensitive. Climatic and prior growth factors in regression explained 87 and 71 percent of the variance of the preditching and postditching earlywood widths, respectively, and 82 and 70 percent of the latewood widths for the same time periods. Early summer precipitation was significantly, and positively, correlated with preditching latewood growth. When pre and postditching records were merged into a single record, regression analysis explained less growth variation than when the two time periods were considered individually, implying a change in growth response following ditching. Prior to ditching, growth was most limited by dry summers which followed dry summers. After ditching, growth was less strongly linked with precipitation and more strongly linked with temperature. Regression results are compatible with the contention that growing season water levels in the proximity of the collection site have been lower since ditching.
\end{abstract}

\section{INTRODUCTION}

The Great Dismal Swamp is a large, forested wetland, straddling the Virginia-North Carolina border on the coastal plain of the eastern United States. Agricultural development of this region, during the past 300 years, has gradually nibbled away at the swamp, particularly along its eastern and southern borders, and reduced it to an area of about $850 \mathrm{~km}^{2}$. The original extent of the swamp is not precisely known, but it seems likely that it may have once occupied an area more than twice its present size.

The largest contiguous part of the Great Dismal swamp is roughly 20 by $50 \mathrm{~km}$ in size with its long axis running north and south. On its west edge, it is bordered by a Pleistocene beach ridge, the Suffolk Scarp (Oaks and Coch, 1973). Although appearing topographically flat, the surface of the swamp slopes gently eastward from the base of the scarp, with an average drop in elevation of about $20 \mathrm{~cm} / \mathrm{km}$. On its north side, the swamp is bordered by U.S. Highway 58, between Suffolk and Portsmouth, Virginia; it is bordered on the east by the Dismal. 
Swamp Canal, and on the south by U.S. Highway 158, in North Carolina (Fig. 1). At present, much of this area is in public ownership, under the administration of the Fish and Wildlife Service, U.S. Department of the Interior, and the State of North Carolina.

Recent work by Oaks and Coch (1973) and by Whitehead (1972) indicates that the Great Dismal Swamp developed on a gently sloping plain of low relief. Radiocarbon dating methods suggest that the accumulation of the organic muck deposits (referred to colloquially as peat) that underlie most of the swamp began approximately 9000 years ago (Whitehead, 1972). Prior to the formation of peat, however, the area was apparently drained by a stream of well-developed dendritic pattern. Accumulations of organic detritus obstructed stream channels and caused the ponding of surface water; well-defined channels eventually disappeared, and the drainage pattern was gradually obscured. The development of peat was self-perpetuating; the accumulation of organic debris created an ever enlarging swampy environment, in which the decomposition of the organic material was extremely slow. The accumulation of peat was often considerable, with thicknesses exceeding 12 feet (Oaks and Coch, 1973).

The Great Dismal Swamp is maintained by water from several sources. Oaks and Whitehead (1978). state that precipitation alone is adequate to maintain the swamp, with annual rainfall averaging 100 to $125 \mathrm{~cm}$ in the Norfolk area. Our observations from a series of shallow wells have indicated that water levels in the peat change rapidly and fluctuate greatly in response to precipitation. In addition to direct precipitation, the swamp receives inflow from several drainage basins west of the Suffolk Scarp, as well as from the scarp itself. The combined discharge from these areas is considerable, as they provide a total catchment area of about $300 \mathrm{~km}^{2}$. The major part of this discharge is in the form of surface flow, which, with rainfall, is an obvious source of water to the Great Dismal Swamp. In addition, some groundwater probably discharges from the shallow aquifer that underlies the swamp and crops out on the escarpment. Lichtler and Walker (1974) have suggested that the artesian flow from this aquifer may be a significant source of water; however, its volume has not been determined. During late winter and early spring, we have also observed seepage of ground water into the swamp from many places along the base of the scarp.

Prior to the formation of the Dismal Swamp peat, the above-mentioned drainage basins appear to have been western extensions of the former dendritic drainage pattern (Oaks and Coch, 1973). As has already been pointed out, the accumulation of peat eventually obscured that part of the drainage pattern east of the scarp. Despite the absence of definite channels, however, surface flow from the streams west of the scarp apparently continued to move eastward across the swamp in broad, anastomosing drainageways that approximated the location of the ancient, pre-peat channels. Shaler $(1890$, p. 317) noted, "There may thus be within the limits of the Dismal Swamp a number of stream valleys which 


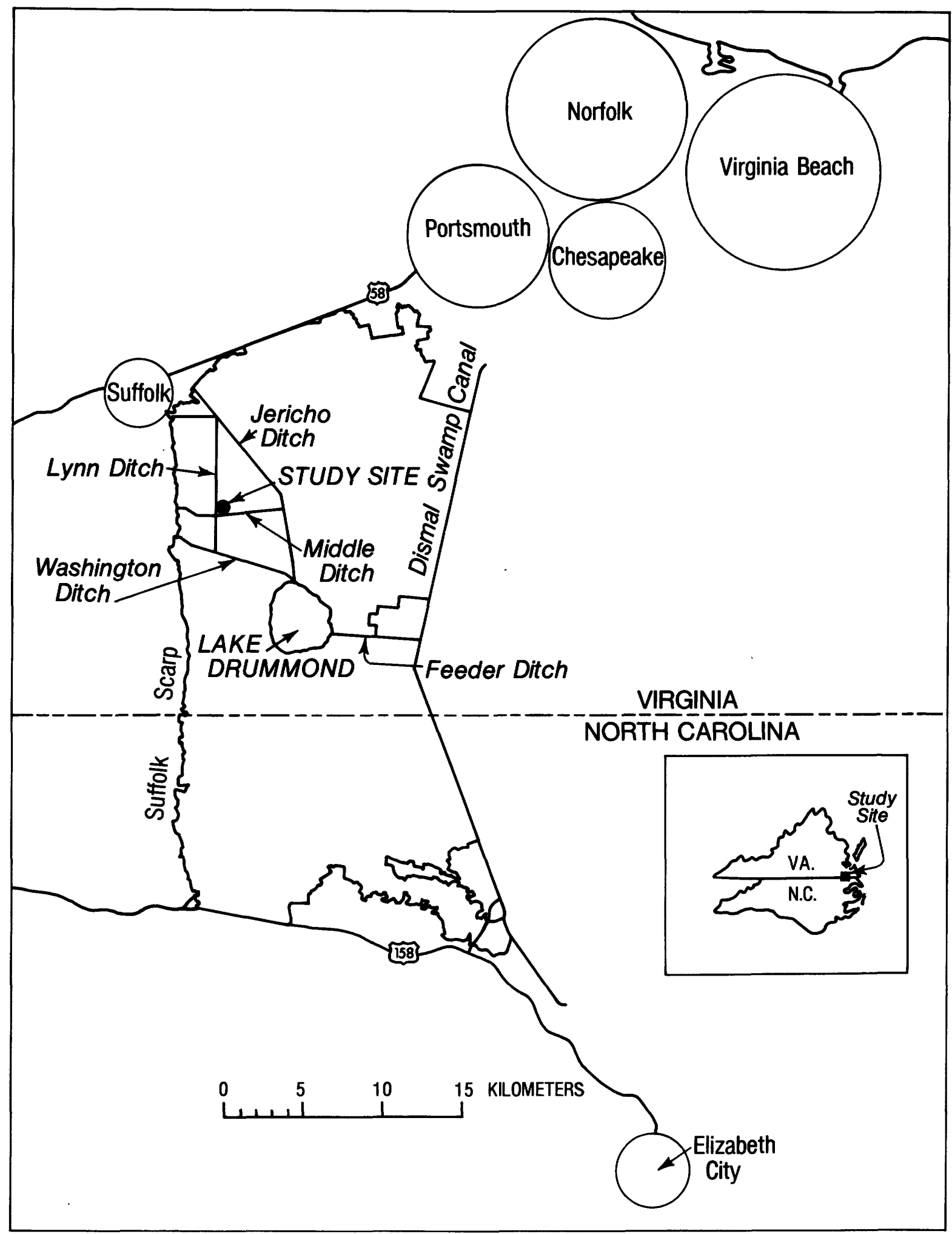

Figure 1. Location of study area in Great Dismal Swamp. Ditch-roads accompany all ditches shown except the Feeder Ditch. Approximate location of nearby towns indicated by circles; Norfolk and Virginia Beach are along seacoast. 
have been so encumbered by the accumulation of vegetable matter that they are no longer evident to the eye."

Timber records, historical accounts, and the presence of stumps indicate that the Great Dismal Swamp was at one time partly dominated by forests of Atlantic white cedar (Chamaecyparis thyoides (L) B.S.P.), often occurring in almost pure stands. Tracts of bald cypress (Taxodium distichum (L.) Richard), black gum (Nyssa sylvatica Marshall), and water tupelo (Nyssa aquatica L.) were dominant in the wetter parts of the swamp, particularly along natural drainageways (Kearney, 1901; Akerman, 1923; Reid, 1952; Dean, 1969). The combined effects of lumbering, burning, and drainage, however, have produced striking changes in the composition of the vegetation of the swamp. Shaler (1890, p. 337) wrote, "Nearly all of the original forest has been removed, culled by the woodmen, or destroyed by fire." He went on to say that the yearly occurrence of forest fires in the dry seasons eradicated not only the growing trees, but also their seeds, as the fires burned to considerable depths in the peat underlying the swamp. Kearney (1901) stated that cypress and white cedar had formerly been much more abundant in the swamp, but because of the high value of these species, they were rapidly logged out. He further stated (p. 423) that "extensive areas formerly covered with juniper (cedar) forest are now almost entirely destitute of trees, and are occupied by woody undergrowth, or even largely by herbaceous plants. Such lands are particularly subject to fires, which effectually prevent the renewal of the forest." He also noted that red maple (Acer rubrum L.) seemed to be increasing in the gum-cypress areas more rapidly than any other species. Indeed, red maple seems to have become the dominant tree species in much of the Dismal Swamp today.

Ditching and canal-building have caused changes in water levels in the Great Dismal Swamp. Long-time residents of the region state that the swamp is "much drier" than it was 20 or 30 years ago. The first major ditch was constructed circa 1770 by the Dismal Swamp Land Company (Brown, 1970). This ditch, which was later named for George Washington, a founder and major stockholder of the company, ran eastward from the base of the Suffolk Scarp, near the mouth of the Cypress Swamp, to Lake Drummond (Fig. 1). The lake, located approximately in the center of the swamp, is a nearly circular body of water about $4 \mathrm{~km}$ in diameter, with a maximum depth of about $2 \mathrm{~m}$. In 1810, Jericho Ditch was constructed from the vicinity of the town of Suffolk, at the northwest corner of the swamp, to Lake Drummond. Both of these ditches were constructed primarily as transportation arteries to provide access to the rich timber resources in the interior of the swamp.

The Dismal Swamp Canal has undoubtedly had the greatest impact on the hydrologic system of the Great Dismal Swamp. Constructed between 1793 and 1805, it roughly bisected the swamp from north to south. The excavated material was piled along both sides of the canal, and formed an effective barrier to the eastward flow of surface water. Shaler (1890 p. 318) noted that "the western dike of the canal serves to retain 
the waters in all that region (that is, the area west of the canal), and at the same time to fend these waters from the region east of the excavation." The effect of the canal on water levels resulted in much litigation between land owners and the Dismal Swamp Canal Company (Brown, 1970); land to the east of the canal gradually dried up, while there was an increase in wetness and flooding on the west side.

It had been assumed that ground water seepage would be sufficient to maintain the water level in the canal, but this turned out not to be true. Eventually, it became necessary to tap Lake Drummond as a water supply, and in 1812 the Feeder Ditch was constructed between the lake and the Dismal Swamp Canal. Prior to 1900, the canal consisted of several levels, separated by locks. The highest, or Summit Level, was connected to Lake Drummond via the Feeder Ditch. During reconstruction, from 1896 to 1899, the canal was greatly deepened and widened, and all locks were eliminated except one at either end. The canal bottom at the Summit Level was lowered by 17.5 feet $(5.3 \mathrm{~m})$ at this time, and the Feeder Ditch was likewise deepened between the canal and Lake Drummond, with a new lock being installed at the Lake Drummond end.

One of the effects of these early ditches and canals was to channel much of the surface water from the swamp. Akerman (1923) noted that, prior to the construction of Washington Ditch, water entering the swamp from the west (that is, from Cypress and Pocosin swamps) tended to spread out and move slowly around to the north of Lake Drummond. With the construction of Washington Ditch, and the subsequent construction of Jericho Ditch and the Feeder Ditch, much of this surface flow was shunted into the Dismal Swamp Canal, via Lake Drummond.

Between 1900 and 1950, few additional ditches were constructed. Many of the older ditches, including Washington Ditch, had been abandoned, and were gradually being overtaken by vegetation and filling in with debris. Between 1951 and 1960, however, approximately $95 \mathrm{~km}$ of ditching was done in the northern half of the swamp (Union Camp, 1971). New ditch construction was accompanied by reconstruction of Washington and Jericho ditches. The earlier ditches had been relatively narrow and shallow, and were bordered by low spoil piles (Akerman, 1923; Mason, 1952). Because of the low capacity of these ditches, and the ineffectiveness of the spoil piles as barriers to surface flow, considerable lateral movement of water occurred across them during periods of high water. The new ditches, however, constructed with modern machinery, are much deeper and wider than the earlier ones and are bordered by large spoil piles that have been graded into roads. The deep, wide ditches have permitted surface water to be drained rapidly from the swamp, whereas the parallel roads have been very effective as barriers to the flow of surface water across the ditches. Although the deep ditches may also intersect underlying aquifers, thus permitting a loss of groundwater to the ditch system (Lichtler and Walker, 1974), the most significant effect of the ditches appears to be on the surface water. 
At the present time, the entire flow from Cypress and Pocosin swamps (fig. 1) is intercepted by the ditch system and channeled into Lake Drummond. Consequently, the broad sheet of water that once flowed eastward across the swamp, north of the lake, no longer exists. Nonetheless, the former drainageway is still readily detectable on color infrared aerial photographs and on satellite images, on which it appears as a band of wet, deciduous forest (Carter and others, 1977). The presence of much bald cypress and water tupelo in the area is further evidence that surface water, often quite deep, was at one time present most of the year.

One of the keys to unlocking the mysteries of the Great Dismal Swamp, particularly with respect to its hydrologic history, may be the use of tree ring data. Trees contain annual records of growth responses to their environment, and thus are of potential value for the examination of past hydrologic or climatic change. This report presents results of an initial study to determine tree-ring sensitivity to swamp climatic and hydrologic conditions, thereby determining the feasibility of using tree rings to examine changes in past hydrologic conditions. If the tree rings were found to be climatically sensitive, then a subsequent objective was to determine if growth responses to climate changed after ditching.

\section{THE STUDY AREA}

The site chosen for the preliminary study is on the east side of Lynn Ditch, $0.5 \mathrm{~km}$ north of Middle Ditch (fig. 1), and north of the former drainageway described above. From early autumn until late spring water is rarely more than $30 \mathrm{~cm}$ deep and occurs in isolated pools rather than in a continuous sheet. Quite possibly, the average depth of water in this area was much greater prior to the construction of the extensive ditch network (including Lynn and Middle Ditches) during the 1950's, and there may have been an eastward flow of surface water. At present, any tendency toward surface flow is effectively blocked by ditch roads adjacent to the ditches. Consequently, surface water in the study area is derived mostly from rainfall and, perhaps, from the upward movement of ground water from the underlying aquifer. It was noted in February 1977, that Lynn Ditch was entirely frozen over except for a short reach of about $50 \mathrm{~m}$ adjacent to the study area. A possible explanation of the unfrozen reach is that groundwater, which was warmer than $O^{*} \mathrm{C}$, was being discharged through the ditch bottom.

A stand of loblolly pine extends about $250 \mathrm{~m}$ along Lynn Ditch and about $500 \mathrm{~m}$ in a generally northeast direction from the ditch. The stand is composed of large pine trees with full crowns and is interspersed with red maple and black gum at all vegetative levels. Tree-ring dating indicates that the stand became established a few years prior to 1830 . 
The organic layer at the study site is 30 to $50 \mathrm{~cm}$ thick. The charcoal at its base may be evidence of a former peat layer destroyed by fire during or following timbering. According to Reid (1952), this section of the swamp was first timbered sometime between 1830 and 1870. Conditions after a fire may have been similar to those in a recently timbered and burned section of the swamp. In the latter area, 30 to $50 \mathrm{~cm}$ of the underlying peat was destroyed, leaving numerous tree stumps perched on their roots, high above the burned surface. In the study area, pine seedlings may have become established on stumps and roots remaining after the fire and thus were protected from inundation during the wet season. The pines remaining seem to be perched on mounds 40 to $60 \mathrm{~cm}$ above the adjacent ground surface. Periodic observations of water levels suggest that even if preditch water levels were no higher than at present, water was probably high enough during parts of the year to kill any young pine seedlings that had become established on the ground surface. However, seedlings germinating on stumps and roots would be less vulnerable to inundation and thus have a greater chance of survival.

\section{TREE-RING DATA}

Preliminary examination of increment cores from loblolly pines at the study site indicated that some trees are characterized by extremely narrow or missing rings for the period corresponding to the early 1950's. For these trees it is seldom possible to accurately date the narrow rings, there being essentially no year-to-year ring width variation. To obtain the final collection, nearly all pines of good form were sampled. If field examination of a core indicated extremely narrow rings for the early $1950^{\prime} \mathrm{s}$, the sample was discarded and the tree tagged accordingly. If the first was acceptable, a second core from the opposite side (generally north or south side) was taken, and the tree was tagged with a collection number. Cores were saved from only about one out of every six trees. The collection is kept on file and is available for inspection at the Tree-Ring Laboratory, U. S. Geological Survey, Reston, Virginia.

The cores were air-dried in paper soda straws, surfaced, crossdated, and their ring widths measured to the nearest $0.01 \mathrm{~mm}$. In pines earlywood is composed of large, light-colored, thin-walled cells added as new tissue early in the growth season. Latewood is composed of smaller, dark-colored, thick-walled cells added as new tissue later in the growth season. The transition from earlywood to latewood is gradual in some pines and more abrupt in others. The earlywood and latewood of the study area samples are quite distinct, permitting separate earlywood and latewood measurements of each ring. The measurements of each core were standardized, or converted to indices, by fitting a straight line or simple curve to the data and then dividing ring widths by corresponding curve values. The computer program for this procedure, which was adapted from a program developed by Fritts and others (1969), not only removes general trends from the data but 
also results in a more-or-less homogeneous variance with time (Fritts, 1976). The indices for all samples were combined to form three chronologies; one each for earlywood, latewood, and total ring width.

Variance characteristics of the chronologies are included in Table 1. The common variance of the chronologies ranged from 41-47 percent, suggesting that local climate is only moderately limiting to tree growth. By comparison, trees on semiarid sites in the southwest can retain as much as 80 percent common variance in the total chronology (Fritts, 1976). The low variance between trees and the greater variance between cores within each tree suggest that crowding and competition of crowns and root systems result in significant differences between different sides of the same tree, but that, as a whole, the study area is uniform. These results seem reasonable, as the study site composes a closed-canopy forest in a homogeneous swamp habitat.

\section{CLIMATIC DATA}

Data of daily temperature extremes and precipitation from Elizabeth City, North Carolina, were utilized for the period 1917-1975 (U.S. Weather Bureau). Elizabeth City is southeast of that part of the swamp presently under public ownership, and is about $40 \mathrm{~km}$ from the study site (fig. 1). Data from five other stations were available, but none except that from Norfolk, Virginia, were as old as 50 years. Norfolk, at the mouth of the Chesapeake Bay, seemed influenced by sea temperatures and breezes. Elizabeth $\mathrm{City}$ is about the same distance from the coast as the Great Dismal Swamp, and so was felt to be more representative of swamp climate than Norfolk.

\section{GENERAL OBSERVATIONS}

One objective of the study was to determine if ditching in the 1950 's might have altered water patterns enough to be reflected in tree growth. A comparison of growth-rate for 20-year periods before and after 1950 indicated no apparent change after ditching (Table 2 ). Six trees showed basal area increases greater than 10 percent after ditching, two showed essentially no change, and three showed decreases of more than 10 percent. The average change of the group was $11 \pm 29$, indicating that for at least the 20 years after ditching, hydrologic change was not great enough to outweigh other environmental factors and to effect a distinct growth response.

As a means of further exploring pre and postditching growth responses, variations in the ring-width pattern after standardization were examined. It was felt that similarities in growth pattern between trees would indicate common response to environmental factors, whereas dissimilarities would indicate specific responses of individual 


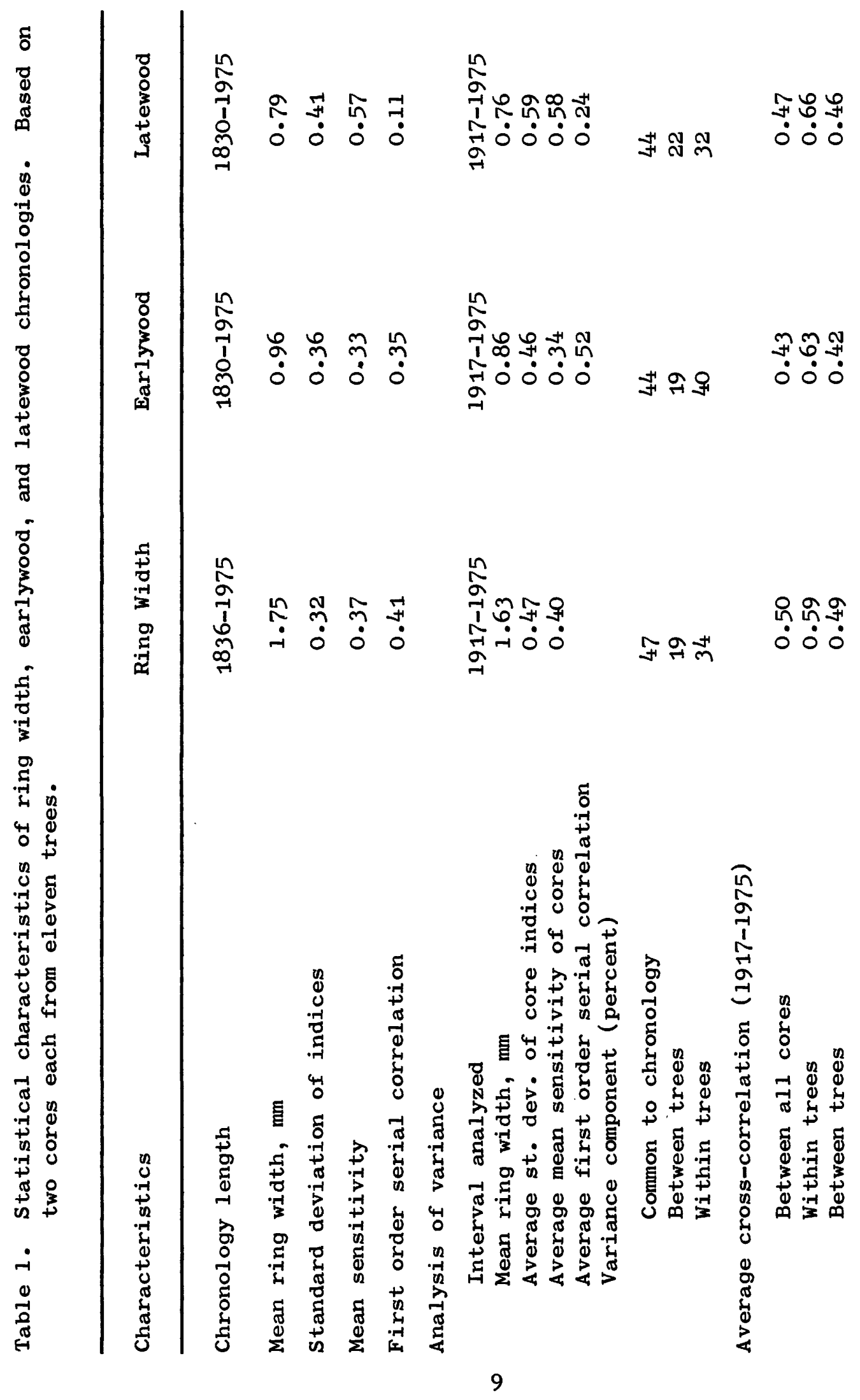


Table 2. Basal area growth of 11 loblolly pines for 20-year increments before and after ditching. Based on raw ring width measurements of two increment cores per tree.

Diameter at

Basal Area $\left(\mathrm{cm}^{2}\right)$

breast height

(cm) 1931-1950 1951-1970 Percent change

\begin{tabular}{cccc}
\hline 38 & 231 & 319 & 38 \\
57 & 239 & 265 & 11 \\
57 & 256 & 377 & 47 \\
65 & 270 & 300 & 11 \\
53 & 289 & 209 & -28 \\
49 & 319 & 254 & -20 \\
66 & 339 & 539 & 59 \\
62 & 396 & 498 & 26 \\
69 & 410 & 404 & -1 \\
84 & 413 & 413 & 0 \\
65 & 647 & 489 & -24 \\
& & & 11 \\
\hline
\end{tabular}


trees to such factors as crowding and shading. To determine general (low frequency) variation in ring width patterns, the data were averaged by use of a low-pass digital filter. Year-to-year variations in tree-ring indices may be thought of as high-frequency variation whereas the general growth trends express very low frequency variation. The filter was designed to pass frequencies where the cycles were approximately 8 years or greater (Stockton \& Fritts, 1971). Examination of the resultant curves for earlywood and latewood of each of the 22 core samples ( 2 cores each from 11 sample trees) revealed a great similarity in pattern between trees.

Plots of the filtered data of the earlywood and latewood chronologies are shown in figure 2. Included in the figure are bars with hatch marks indicating the average and standard deviation of each fifth year of the filtered data of all 22 cores from 1920 to present. Though the standard deviations indicate considerable variations between cores, a general pattern is evident. A growth peak in the late 1920 's is followed by a steady decline to about 1950, a rapid increase for 8 to 10 years, and then, decline to 1970 .

It seemed evident from the growth-trend variations (filtered data) that the trees were responding to something common to all of them. Therefore, climatic data were subjected to the same filtering techniques to determine if any climatic variations matched growth-trend variations. Some definite trends are evident in the climatic data (figure 3) but correspondence with growth variation for the length of record is not obvious. However, when considering only parts of the time period, during 1920-70, some correspondence between May to mid-June precipitation and growth may be noted. A pronounced precipitation peak in the late 1920 's matches with a growth peak, and a smaller precipitation peak around 1950 matches with a period of reduced growth. However, a third rainfall peak in the 1960's seems to correspond neither to increased nor decreased growth, meaning that no consistent relationships between trends in climate and trends in growth is apparent.

In summary, 20-year growth rates do not distinguish differences before and after ditching. Further, a distinct pattern of growth-trend variation that does not correspond to any climatic trends tested suggests a nonclimatic influence. This is not to say that year-to-year variations in tree growth do not respond to, or are limited by, climate, but simply that growth trends during 1920-70 seem independent of climatic trends.

\section{REGRESSION ANALYSIS}

To further explore the possibility that tree growth might have been influenced by ditching, additional tests were made by regression analysis of yearly growth indices with seasonal climate. These tests are described below. Stepwise multiple regressions were run, using 

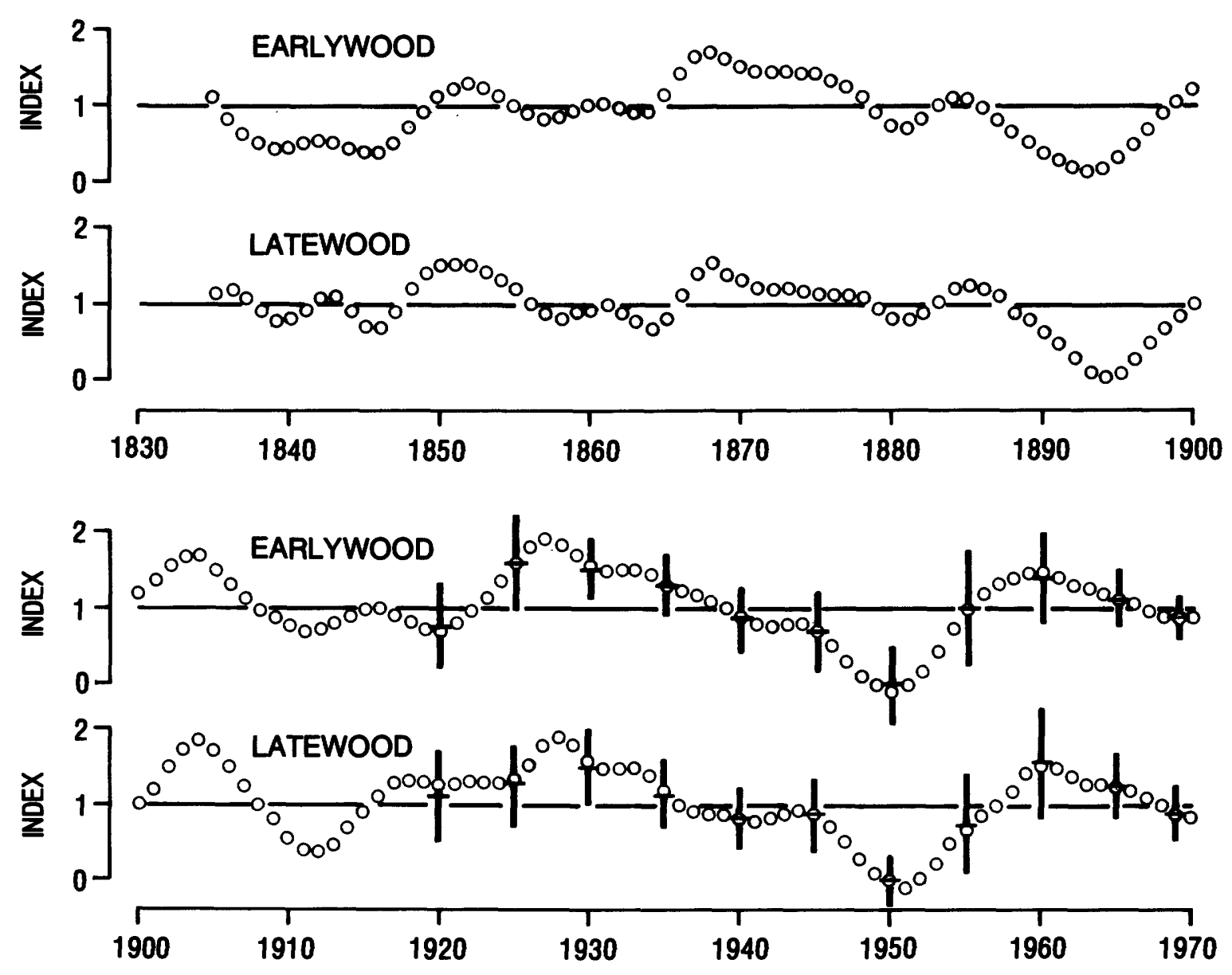

Figure 2. General trends in ring-width, 1835-1970. Trends were determined by averaging indices with a low-pass digital filter. Average and standard deviation for each fifth year for all 22 samples is indicated for the analysis period after 1917. 

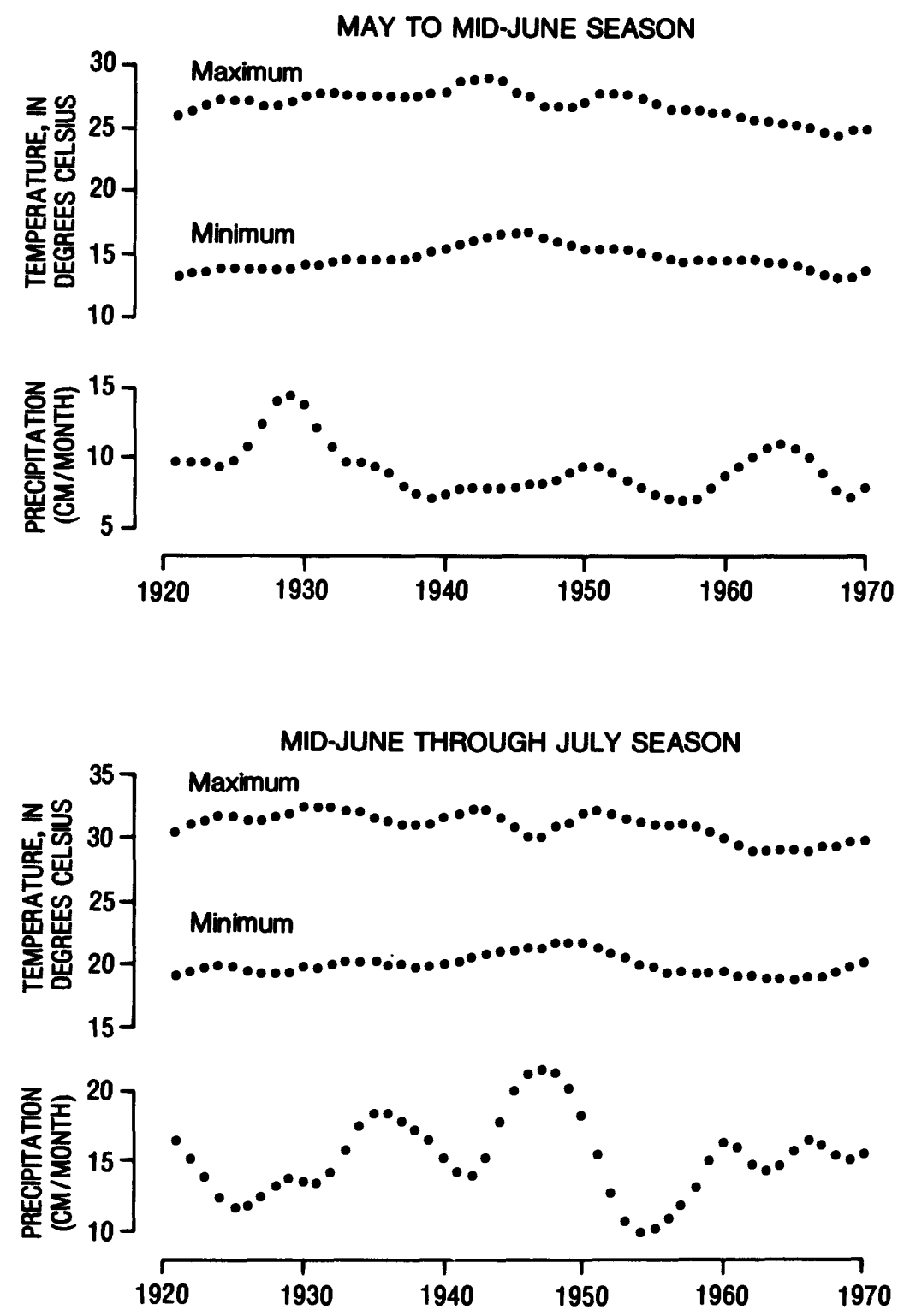

Figure 3. Filtered temperature and precipitation data for Elizabeth City, North Carolina.

Only late spring (May to mid-June) and early summer (midJune through July) are shown. Precipitation is expressed as centimeters and temperature as degrees Celcius. 
climatic data as independent variables and tree-ring indices as dependent variables. If the time series analyzed contains many years, then it might be justifiable to examine many independent (environmental) variables. However, since the time periods of interest in this study composed relatively few years, and since a degree of freedom is lost for each variable entered into regression, it was felt desirable to limit the number of variables available for entry.

It was expected that, as is common in analyses between tree rings and climate elsewhere (Fritts, 1976), growth of the swamp loblolly would show responses to temperature and precipitation during the year prior to growth as well as to conditions concurrent with growth. Preliminary analyses suggested that some times during the year factors are not as influential as others, and so could be lumped together as a means of limiting the number of potential variables. Various combinations of months or seasons were tried. For final analysis average maximum temperature, average minimum temperature, and total precipitation were each used as variables for each of the following seasons:

May to mid-June prior to growth ( 1.5 months), assumed to be period of earlywood growth of prior year,

mid-June through July prior to growth ( 1.5 months), assumed to be period of majority of latewood growth of prior year,

August through October prior to growth ( 3 months), thought to be period of leaf bud development and food accumulation,

November through April prior to growth ( 6 months), thought to be period of relative dormancy and soil-water replenishment.

May to mid-June concurrent with growth ( 1.5 months), period of earlywood growth, and

mid-June through July concurrent with growth (1.5 months), period of latewood growth.

In addition to the eighteen climatic variables thus calculated, one or two variables representing prior growth were also included to help account for serial correlation of the tree-ring data. Stepwise multiple regression was performed on indices of each core sample from every tree, as well as on chronologies of earlywood, latewood, and total ring width. As results of analyses with chronologies seemed reasonably representative of the individual samples as a whole, only results with chronologies are reported.

Table 3 summarizes percent variance accounted for by regression between chronologies and climate (including prior growth). When the entire length of record (1917 - 1975) was considered, climate accounted for only 54 percent of the total ring-width variance. However, when the length of record was subdivided into pre and postditching segments, climate accounted for 72 percent and 67 percent, respectively, of the variance. When earlywood and latewood growth data were analyzed separately, climate accounted for 87 percent of earlywood growth and 82 
Table 3. Percent variance $\left(R^{2} \times 100\right)$ accounted for by regression between chronologies and variables for climate plus prior growth.

\section{Chronology}

Earlywood Latewood Ring Width

$1917-1950$

(preditching)

87

82

72

1951-1975

(postditching)

71

70

67

1947-1975

69

74

54 
percent of latewood growth during the preditching era; after ditching, climate accounted for only 71 percent of earlywood growth and 70 percent of latewood growth. Had relationships between climate and growth been constant with time, splitting the time period of the analysis into two shorter periods would have decreased the variance explained by regression because of the loss of degrees of freedom. However, the fact that a much greater part of variance was explained when pre and postditching periods were analyzed separately strongly suggests that climatic effects on growth were different before and after ditching.

Figure 4 contains graphic representation of results of stepwise multiple regression of earlywood and latewood chronologies for pre and postditching periods. Climatic factors considered were average daily maximum and minimum temperatures per season and total precipitation per season, where the seasons were determined as described above for Combination III. Variables for prior earlywood and latewood growth were also included to account for the serial correlation of growth. There was one variable for each of the six seasons for maximum and minimum temperature and precipitation, and two prior-growth variables, giving a total of 20 variables available for entry into regression. The bar graphs represent all variables entered into regression (fig. 4).

Preditching earlywood growth responded most significantly to previous August to October maximum temperatures, with significant negative correlations indicated for previous May through July precipitation and previous May to mid-June minimum temperature. Current May to mid-June precipitation was also picked by the stepwise process but did not seem highly significant. Thus, earlywood growth seemed to be influenced more by conditions of the previous season, especially by the previous autumn temperature, when growth had nearly stopped, but temperatures were still warm enough for photosynthetic food production and storage.

Preditching latewood growth was positively correlated with precipitation for mid-June through July, the time, it is speculated, when most latewood growth occurs. Excessive rainfall in swampy areas inundates the root systems, thereby reducing gas exchange between roots and "soil" and resulting in "physiological drought" and reduced growth. Evidently, by early summer (mid-June through July) the water levels in the peat are typically low enough that rains do not unduly inundate the root systems. Furthermore, rainfall may raise the water to a level closer to the shallow root systems, thereby making it more readily available to the trees. On the other hand, rainfall in a wet environment may be less important to growth than the effects of cloud cover and high humidity. During wet, rainy summer months, high humidity and reduced heat load on the leaves reduce transpiration stress, resulting in increased growth. 
EARLYWOOD CHRONOLOGY 1917-1950 $\left(R^{2}=0.8690\right)$

MONTHS

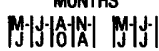

PRECIPTTATION
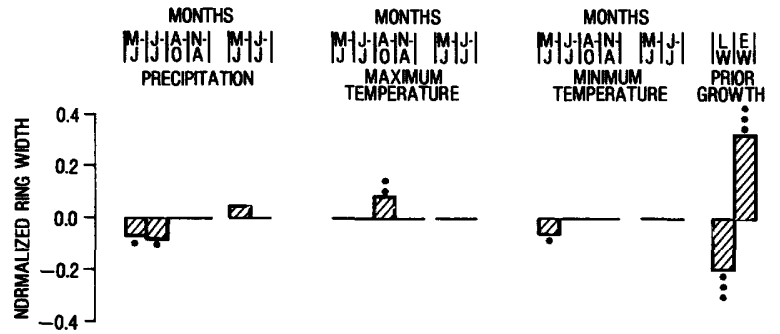

EARLYWOOD CHRONOLOGY $1951-1975$ (R2=0.7072)

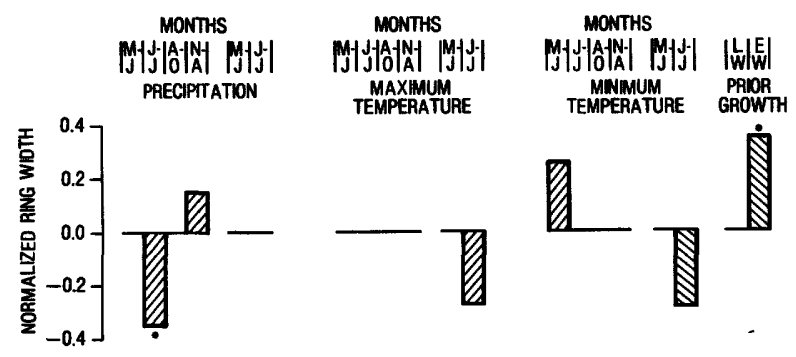

LATEWOOD CHRONOLOGY $1951-1975\left(\mathrm{R}^{2}=0.7015\right)$

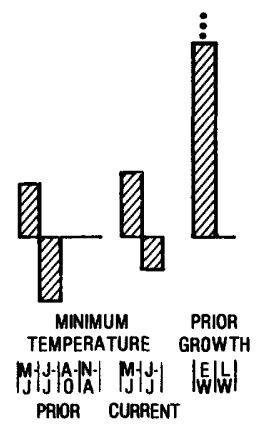

Figure 4. Stepwise multiple regression results from analysis of ring widths of Pinus taeda for time periods before ditching (1917-1950) and after ditching (1951-1975) in the Great Dismal Swamp, Virginia. Variables available for entry into stepwise regression included total seasonal precipitation, average daily maximum and average daily minimum temperature per season for seasons from late spring prior to the season of growth through early summer concurrent with growth. See text for definition of seasons. The bars represent standardized regression coefficients for all variables selected by the stepwise process (selection required $F$ ratios greater than 1). Number of dots indicates significance level:

- $\geq 0.95, \ldots \geq 0.99, \ldots \geq 0.999$. 
Of further interest is the fact that spring minimum temperatures are positively correlated with growth, and summer minimums are negatively correlated with growth (fig. 4). This suggests that spring minimum temperatures are normally low enough that any increase would aid in food manufacture, whereas summer minimum temperatures are normally high enough that any increase in them would increase respiration and transpiration sufficiently to reduce the net gains of produced foods.

Results of postditching regressions (fig. 4) indicate that increased summer rainfall causes some increase in latewood growth and significantly reduces earlywood growth of the following year. Compared with preditching responses, the effect is smaller on current latewood growth and greater on the following year's earlywood. Following the above reasoning, it would seem that after ditch construction, the trees experienced less water stress during typical summers; in other words, growth increased during rainy summers before and after ditching, but the increase was less significant after ditching.

Of particular interest was the fact that postditching earlywood growth was negatively correlated with both maximum and minimum summer temperatures (mid-June through July) even though most earlywood growth typically occurs during the May to mid-June period. By way of explanation, it may be that increased summer temperatures are indicative of a hotter, drier summer, under which conditions the transition from earlywood to latewood occurs earlier, resulting in less earlywood growth. In the preditching period, however, summer temperatures seemed to have little or no effect on earlywood growth.

Although the effect of a rainy summer was to increase latewood growth during the current year, in both pre and postditching periods, the increase was generally smaller after ditching. The result of a dry summer was to decrease earlywood growth, both in the current year and the following year, in pre and postditch periods; however, the decrease in earlywood growth was greater after ditching. In conclusion, it would seem that ditching modified the effect of increased summer rainfall; that is, increase in growth associated with wetter summers was smaller. On the other hand, after ditching, the effect of decreased summer rainfall was more pronounced, with a greater decrease in growth associated with drier summers.

A lowered water table allows a reasonable explanation of changes in growth responses ascribed to ditching (fig. 5). With normal amounts of summer rainfall, the lower average water levels resulting from ditching would be expected to cause greater internal water stresses and reduced growth relative to preditching conditions. If water availability to the roots is further reduced by less-than-normal rainfall, then growth, as borne out by regression, is even further reduced. Increases in rainfall partially compensate for the normally reduced 


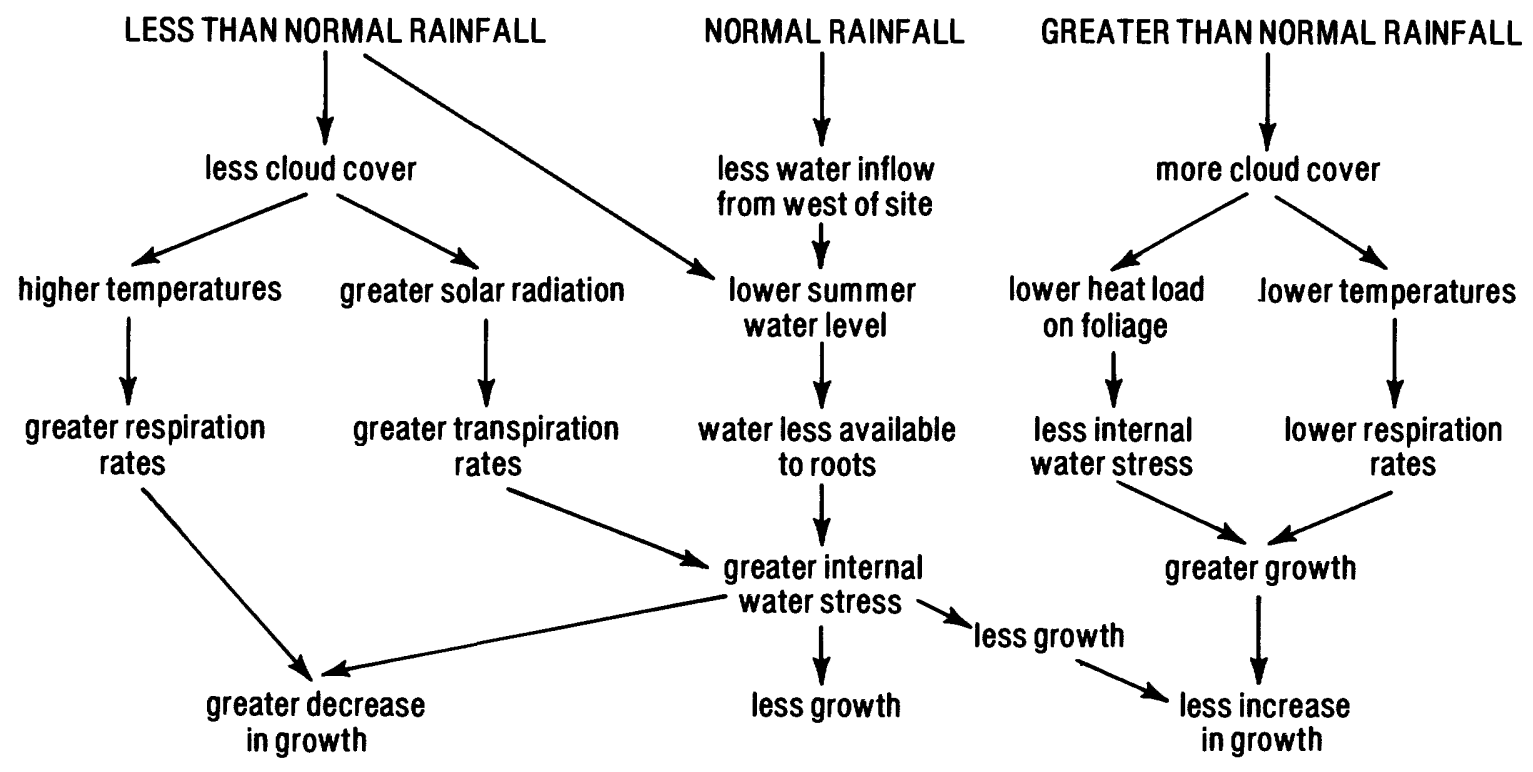

Figure 5. Changes in growth response to rainfall after ditching. 
availability of water, but, as shown by regression, the growth response is not as marked during postditching conditions as it is during preditching ones.

The indications of greater decreases in growth during and after dry summers, and smaller increase during rainy summers, suggest that, overall, growth after ditching should be expected to be less than growth before ditching. This however, is not confirmed by comparisons of growth for 20-year periods before and after ditching (table 2). It seems possible that as a result of lower water levels after ditching there may have been growth of the root systems to greater depths. Increased root system size would tend to negate the postditching effects described above and result in increased growth (fig. 2: mid-1950's to mid-1960's). With environmental conditions in the root zone more favorable to growth, poorer correlations with climate would result, which would account for much of the unexplained variance of postditching growth (table 3). With continued expansion of the root systems, competition between systems would increase; climatic factors would again become more limiting, and a decline in growth rates would result. Thus, the growth peak around 1960 may simply be the result of root release after lowering of the water levels and it is somewhat analogous to crown release after lumbering.

Results of regression analysis may be summarized by describing conditions associated with the formation of narrow tree rings (table 4 ). Generally, before ditching, narrow rings were formed during a dry year that followed a wet year. After ditching, narrow rings were most commonly formed during a dry year that followed a dry year. Before ditching, narrow earlywood formation was associated with wet and cool conditions of the previous season and narrow latewood with current dry, warm summers. After ditching, there was some indication that narrow earlywood followed wet summers, and that narrow latewood was a result of wet summers followed by dry summers.

Years of narrow rings by total ring, earlywood, and latewood are listed in table 5. Also indicated are years after 1917 in which climatic conditions leading to reduced growth are satisfied. As indicated in the table, reduced growth occurred about twice as often as conditions warranted. In addition (now shown in the table) there were years in which conditions for reduced growth seemed to be indicated, but in which growth was not significantly reduced. Though entries in the table cannot be used for climatic reconstruction, note that of the 8 years of reduced growth after 1917, 6 were years that seemed conducive to narrow ring formation. The exceptions, 1948 and 1949, were in the midst of an extended period of reduced growth. The extended periods of reduced growth in the 1890's and 1940's (see also fig. 2) seem to be exceptions to the regression results as described. These could represent extended droughts in the swamp, not reflected by seasonal averages of climatic variables used in regression. 
Table 4. Conditions resulting in narrow rings in Pinus taeda.

Preditching

\begin{tabular}{lll}
\hline Total & Earlywood & Latewood \\
Ring Width & Only & Only
\end{tabular}

\begin{tabular}{|c|c|c|c|}
\hline prior May, June & wet*, warm* & wet, warm & $\operatorname{cool}^{*}$ \\
\hline prior June, July & wet $* * *$ & wet & $\overline{\operatorname{cool}} *$, warm* \\
\hline prior August - October & wet*, $\overline{\text { cool }}$ & $\operatorname{cool} * *$ & wet* \\
\hline prior November - April & no effect & no effect & no effect \\
\hline current May, June & dry*, cool $^{*}$ & dry* & $\mathrm{dry}^{*}, \overline{\operatorname{cool}^{*}}$ \\
\hline eurrent June, July & dry, $\overline{\text { wa }}$ & no effect & dry*, warm* \\
\hline
\end{tabular}

Postditching

$\begin{array}{lll}\text { Total } & \text { Earlywood } & \text { Latewood } \\ \text { Ring Width } & \text { Only } & \text { Only }\end{array}$

\begin{tabular}{|c|c|c|c|}
\hline prior May, June & cool & $\mathrm{cool}^{*}$ & no effect \\
\hline prior June, July & warm* & wet & no effect \\
\hline prior August - October & warm* & no effect & wet*, warm* \\
\hline prior November - April & dry & dry* & no effect \\
\hline current May, June & no effect & no effect & no effect \\
\hline current June, July & dry, warm** & $\overline{\text { warm* }}$ & dry* \\
\hline
\end{tabular}

\footnotetext{
* = significant at 95 percent

** - significant at 99 percent

$* * *=$ significant at 99.9 percent

$=$ maximum temperature

$=$ minimum temperature
} 
Table 5. Years between 1830-1950 (period before extensive ditching) in which the growth index was less than the mean minus the standard deviation. Type of growth is identified as total ring width $(T)$, earlywood (E), or latewood (L).

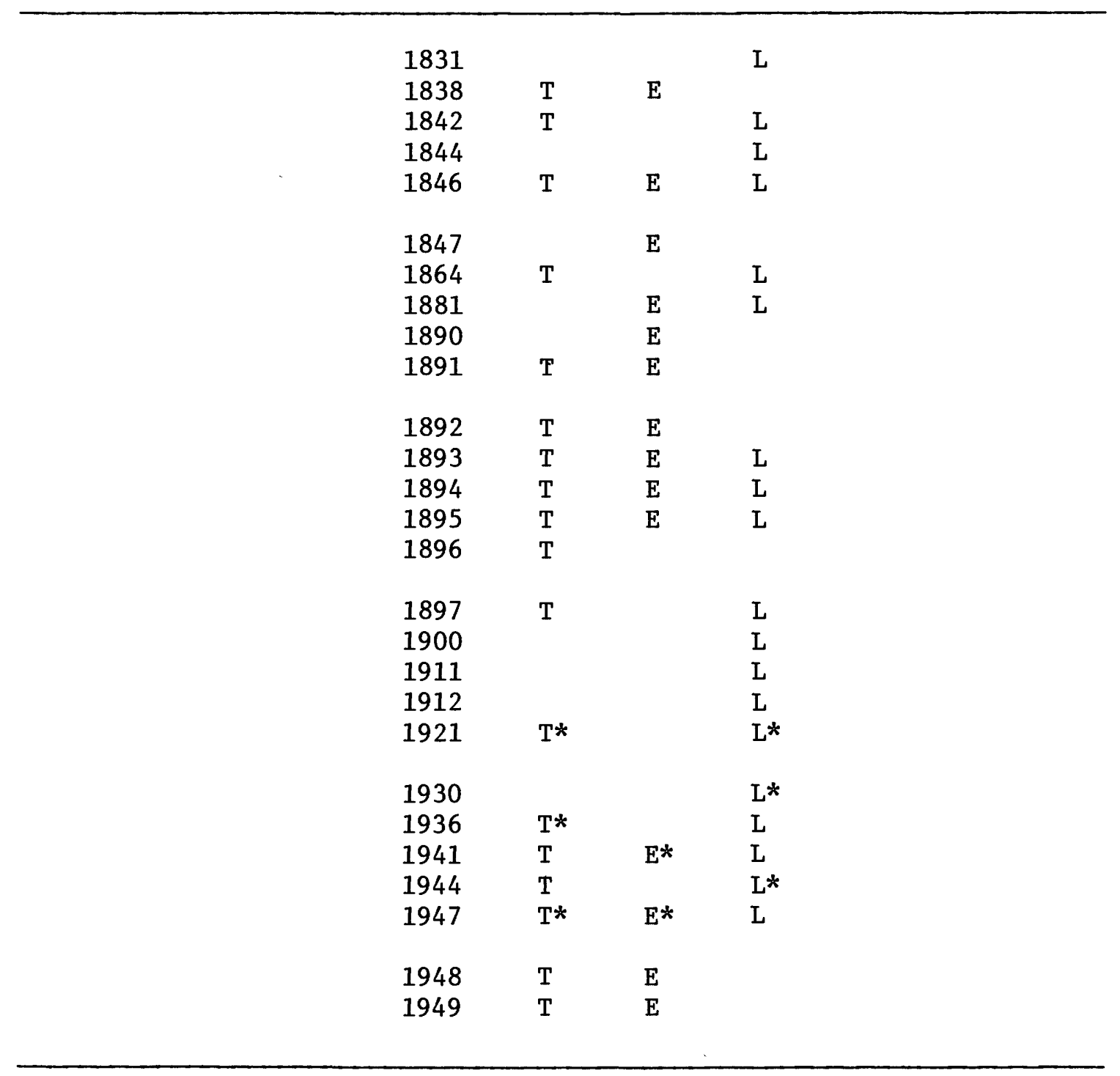

* Years after 1917 with climatic conditions, determined by regression, to be conducive to reduced growth. 
An analysis of tree rings of large loblolly pines growing near Lynn Ditch in the Great Dismal Swamp was conducted as part of a study to determine climatic sensitivity of tree rings from trees in wetland habitats. Of particular concern was whether tree growth might provide evidence of changes in hydrologic conditions after ditching.

Tree rings from increment core samples from 11 trees were found to cross-date with each other, and analysis of variance suggested that growth is at least moderately correlated with climate.

Basal area increments of each sample tree were examined for 20-year periods before and after 1950, the approximate date at which ditch construction began. No significant growth difference was noted between pre and postditching periods.

Tree ring indices and seasonal values of temperatures and precipitation were examined for trend variations by the use of low pass digital filter techniques. A similarity in patterns between trees is indicated. However, the pattern did not correspond significantly with trend variations in climatic factors tested. It is probable that low frequency growth variations are related to regional environmental conditions not tested for. Among these conditions cycles of low water levels in the swamp peat are considered most likely.

Yearly variations in growth were compared with yearly variations in seasonal climate by the use of stepwise multiple regression. Only about half of the variance of total ring width for the period of record, 1917-1975, was explained by climate and prior growth. When the time period was divided into pre and postditching segments, more than twothirds of the growth variance was explained by climate and prior growth and the degree to which various factors limited growth was found to be different after ditching. It is suggested that hydrologic change as a consequence of ditch construction was the most likely cause of changed growth responses to climate. Before ditching, total ring width was mostly limited by rainfall, with narrow rings being associated with dry summers that followed wet summers. After ditching, growth seemed to be limited more by temperature than by rainfall.

Further examinations of growth responses were afforded by dividing the annual growth increments into earlywood and latewood components. With such division, temperature, precipitation, and prior growth accounted for about three-fourths of the tree-ring variance. Narrow earlywood widths formed before ditching were associated with cool temperatures of the preceding fall and warm, wet conditions of the previous summer. After ditching, narrow earlywood widths were strongly associated with wet summers of the previous year. Narrow latewood 
growth before ditching was significantly linked with dry summers. After ditching, dry summers were only weakly associated with narrow latewood. Overall, in both pre and postditching periods, latewood growth seemed to be limited more by earlywood growth of the same year than by climate.

Changes in growth responses after ditching were explanable when it was assumed that water levels in the peat after ditching were lower than before ditching. However, it is emphasized that this observation is based on samples from a small area near the Lynn Ditch-Middle Ditch intersection. Though other areas in the swamp may be similar, it seems probable that the effects of ditching on water levels throughout the swamp are highly variable. Furthermore, this study has provided no evidence that species composition has responded to any hydrologic change consequent to ditching.

The pines at the study site were more than 120 years old at the time of ditching in the 1950's, probably having become established on stumps and roots remaining after a peat fire before 1830. Since establishment of the pines, peat seems to have accumulated at an average rate of $30 \mathrm{~cm}$ per 100 years. Construction of Lynn Ditch in the early 1950's evidently resulted in lowered water levels in the study site. It is concluded that after ditching, root growth probably increased, with the consequence that, in compensating for lowered water levels, the trees have become less limited by, and growth is thus more poorly correlated with, droughty growth seasons. Extended periods of narrow tree rings were noted for the $1890^{\prime} \mathrm{s}$ and also about 1950 . It is speculated that these may represent extreme droughty conditions in the swamp, which were not indicated by climatic factors used in regression.

Tree-ring data used in this report are on file at the Tree-Ring Laboratory, National Center, Reston, and at the International Tree-Ring Data Bank, Tucson, Arizona. 


\section{REFERENCES}

Akerman, Alfred, 1923, The white cedar of the Dismal Swamp: Virginia Forestry Pub. no. 30, Virginia Geological Commission, 21 pp.

Brown, A. C., 1970, The Dismal Swamp Canal: Norfolk County Historical Society, Chesapeake, Virginia, $234 \mathrm{p}$.

Carter, Virginia, Garrett, M. K., Shima, Lurie, and Gammon, Patricia, 1977, The Great Dismal Swamp: management of a hydrologic resource with the aid of remote sensing: Water Resources Bu11., v. 13, no. 1, p. $1-12$.

Dean, G. W., 1969, Forests and forestry in the Dismal Swamp: Virginia Jour. Sci., v. 20, no. 4, p. 166-173.

Fritts, H. C., 1976, Tree rings and climate: New York City, Academic Press, $567 \mathrm{p}$.

Fritts, H. C., Mosimann, J. E., and Bottorff, C. P., 1969, A revised computer program for standardizing tree-ring series: Tree-Ring Bul1., v. 29, p. 15-20.

Kearney, T. H., 1901, Report on a botanical survey of the Dismal Swamp region: U.S. Department of Agriculture, Contributions from the U. S. National Herbarium, v. 5, no. 6, p. 321-550.

Lichtler, W. F., and Walker, P. N., 1974, Hydrology of the Dismal Swamp, Virginia-North Carolina: U. S. Geological Survey Open-File Report, 200 West Grace Street, Richmond, Virginia 23220.

Mason, C. R., 1952, Mapping in Dismal Swamp: The Military Engineer, v. 44 , no. 298 , p. 120-125.

Oaks, R. Q., Jr., and Coch, N. K., 1973, Post-Miocene stratigraphy and morphology, southeastern Virginia: Virginia Division of Mineral Resources Bulletin 82, 135 p.

Oaks, R. Q., Jr., and Whitehead, D. R., 1978, Geologic setting and origin of the Dismal Swamp, southeastern Virginia and northeastern North Carolina. Proc. First Dismal Swamp Symposium, Norfolk, Va., 1974, (in press).

Reid, J. H., 1952, Reports to Camp Manufacturing Company on timber holdings of Camp, Richmond Cedar Works, Roper Lumber Company, and other landowners in the Great Dismal Swamp: Typewritten reports on file in offices of Union Camp Corporation, Franklin, Virginia. 
Shaler, N. S., 1890, General account of the fresh-water morasses of the United States, with a description of the Dismal Swamp District of Virginia and North Carolina: 19th Annual Report to the Director, U. S. Geological Survey, p. 255-339.

Stockton, C. W., and Fritts, H. C., 1971, Conditional probability of occurrence for variations in climate based on width of annual tree rings in Arizona: Tree-Ring Bull. v. 31, p. 3-24.

Union Camp Corporation, 1971, Dismal Swamp study 1659-25, Prepared by Charles T. Main, Inc., Engineers: Duplicated report on file at Great Dismal Swamp National Wildlife Refuge, Suffolk, Va.

U. S. Weather Bureau, Climatological Data, 1917-1977.

Whitehead, D. R., 1972, Developmental and environmental history of the Dismal Swamp: Ecological Monographs, v. 42, no. 3, p. 301-315. 